Predrag S. Mirčetić*

Univerzitet u Beogradu, Filološki fakultet

\title{
SANJAR ĐOTO U PaZOLINIJEVOM DEKAMERONU
}

\begin{abstract}
Prema zbirci novela Dekameron Pjer Paolo Pazolini je 1971. godine snimio prvi deo Trilogije života. U filmu Dekameron učenik slikara Đota putuje u Napulj umetničkog stvaralaštva radi, što čini okvir koji povezuje priče preuzete iz Bokačovog dela. U radu se bavim uticajem Pazolinijeve književne i filmske poetike na adaptaciju Dekamerona, rediteljevom reinterpretacijom Bokačovog koncepta ljubavi, te transmedijalnom ulogom Đota i njegove umetnosti. Eros u Pazolinijevom filmu, kao i promena okvirne priče, protumačeni su na osnovu sećanja na predavanja Aleksandra Ilića o konceptu ljubavi i o nosećoj priči Bokačovog Dekamerona.
\end{abstract}

Ključne reči: Pjer Paolo Pazolini, Dekameron, Đovani Bokačo, Aleksandar Ilić.

Film Dekameron (Il Decameron, 1971), snimljen prema istoimenoj Bokačovoj (Giovanni Boccaccio) zbirci novela, predstavlja prvi deo Trilogije života (La Triologia della vita); druga dva filma iz trilogije su Kenterberijske priče (I racconti di Canterbury, 1972) i Cvet hiljadu i jedne noći (Il fiore delle Mille e una notte, 1974), režirani na osnovu dela srednjovekovnog engleskog pisca Džefrija Čosera (Geoffrey Chaucer), odnosno zbirke pripovedaka koju uokviruje pripovest o slavnoj Šeherezadi.

Pazolini, kontroverzni umetnik, bio je intelektualac širokog spektra interesovanja: pesnik, romanopisac, esejista, scenarista, filmaš, kontraš i marksista. Kao intelektualna figura ne samo italijanske već i evropske kulturne scene šezdesetih i sedamdesetih godina prošloga veka, široj publici danas je poznat prevashodno zbog svog rediteljskog opusa - 23 filma nastala u roku od samo 15 godina $^{1}$ - a tek onda zbog svog levičarskog intelektualnog angažmana ${ }^{2}$, te tragične smrti koja je

* predrag.mircetic@fil.bg.ac.rs

1 Pored pomenute Trilogije života, kao najvažniji filmovi izdvajaju se sledeći naslovi: Skitnica (Accattone, 1961), Mamma Roma (1962), Rikota (La Ricotta, 1963), Jevanđelje po Mateju (Il Vangelo secondo Matteo, 1964), Ptičurine i ptičice (Uccellacci e uccellini, 1966), Kralj Edip (Edipo re, 1967), Teorema (Teorema, 1968), Svinjac (Porcile, 1969), Medeja (Medea, 1970) i Salo ili 120 dana Sodome (Salò o le 120 giornate di Sodoma, 1975). Sadržaj pojednih filmova, kao i analizu njihovih karakterističnih postupaka videti u: Repetto 1998: 55-137.

2 Odnos Pazolinija i levice nije lišen kontradiktornosti ni u životu ni u umetnosti. Prema Stefanu Sočiju (Stefano Socci), „levica nije volela Pazolinija“ (Аранђеловић 2004: 75). Bio je isključen iz Komunističke partije Italije 1949. 
napravila od njega svojevrsnog mučenika ${ }^{3}$ i književnog stvaralaštva ${ }^{4}$. Moravija (Alberto Moravia), za koga je Pazolini „najveći italijanski pesnik druge polovine“ dvadesetog veka - drugačije vrednuje Pazolinijevo stvaralaštvo: „usled visokih ciljeva i uspešnih ostvarenja, njegova režijska dela, treba postaviti odmah iza poetskih, a ispred romansijerskih“ (isto: 11). Budući da „scenarističko iskustvo“, ali i pisanje uopšte, predstavlja „neophodnu osnovu za prelazak na režiju“ (Feroni 2005: 565), može se govoriti o sličnosti između Pazolinijevog književnog i filmskog stvaralaštva.

U prilog jedinstvu književne i filmske poetike mogu se navesti reči samog Pazolinija - kao nastavak „pesničkog rada“ izabrao je „kinematografiju“, kako bi pronašao „stvarnost u njenoj lepoti, u njenoj poeziji“; umetnikova „priroda [se] nije promenila prelaskom sa literature na film“ (Аранђеловић 2004: 57, 49). Doduše, Pazolini napominje kako je mislio da „prelaz sa literature na film uključuje samo promenu tehnike“, ali da je „uranjajući sve dublje u medij“ shvatio da „film nema literarnu tehniku“ već „sopstveni jezik“ (isto: 49). Vremenom je formulisao shvatanje da „film kao sistem znakova“ jeste „nekonvencionalni i nesimbolički jezik (linguaggio)“ koji stoji „nasuprot pisanom ili govornom jeziku (lingua), i da izražava realnost ne kroz simbole već putem realnosti“ - „ako želim da izrazim drvo, izraziću ga kroz njega samog“ (isto: 49, 50). U pozadini shvatanja da film ,izražava realnost realnošću“, međutim, ne leži nikakva naturalistička estetika.5 Prema Pazoliniju, filmska „semiologija korespondira sa mogućom semiologijom

godine, a 1968. godine dospeo je, zbog svoje kritike studentskih protesta i nove levice u pesmi KPI mladima, „u paradoksalnu situaciju da policajce, proleterskog porekla, brani od studenata, tatinih sinova, buržuja i malograđana" (Feroni 2005: 565). Kada je o umetnosti reč, Pazolini je imao kritički odnos spram marksističke estetike: „Ništa ne može toliko da uništi umetnost koliko pokušaj da se na nju primeni marksizam ili da se ona pripoji marksizmu“ (Аранђеловић 2004: 16). Prema Pazolinijevom shvatanju marksistička estetika „nije izmislila ništa analogno dualizmima, dijalektičkim ili ne“, već je „izrodila socijalistički realizam, nebrojenu uzornu verziju umetnosti - $\mathrm{i}$ [to] sa idealističke tačke gledišta“ (isto: 16) [kurzivom istakao P. M.].

3 „Pazolinijeva smrt urezala se u kolektivnu svest kao akt žrtvovanja, kao mučeništvo koje njegovo očajničko i opsesivno upućivanje izazova savremenom dobu kao da je zahtevalo“ (Feroni 2005: 565). Umetnikovu „brutalnu smrt“ „mnogi povezuju sa činjenicom da je on godinama bio najglasniji i najuporniji (omraženi) kritičar korupcije u koju su ogrezle policija, crkva, vlada i država u Italiji“ (Аранђеловић 2004: 8).

4 Kao pisac Pazolini se istakao u svim žanrovima: poeziji, romanima, dramskim komadima, ali i esejima koji se prema tematici mogu podeliti na angažovane (u njima se bavi političkim i društvenim problemima) i kulturne (u njima se bavi pitanjima jezika, književnosti, umetnosti i kulture uopšte).

5 Uporediti sa sledećim Pazolinijevim stavovima: „Mrzim prirodnost. Ja rekonstruišem sve.“ „Mrzim osobenosti i mrzim naturalizam, tako da glumci neizbežno 
sistema znakova i same realnosti“ (isto: 50), a što upućuje na njegov koncept semiologije života (Pasolini 2008: 1680-1683). ${ }^{6}$

Gledano iz ugla poetike, Pazolini predstavlja sasvim osobenu figuru u istoriji italijanske kinematografije. ${ }^{7} \mathrm{Za}$ razliku od Godara (Jean-Luc Godard) ili Čaplina (Charles Chaplin) koji su izumeli sopstvene stilove, Pazolini za sebe tvrdi da je „pastišer po strasti, a ne po kalkulisanju“: „Moj [stil] se sastoji iz različitih stilova. Ako vidite i mali deo nekog mog filma možete reći da je moj [ne po stilu već] po tonu“ (Аранђеловић 2004: 49). Iako neki Pazolinija svrstavaju u neorealizam zbog filmova Skitnica i Mamma Roma, treba imati na umu da Pazolini snima šezdesetih i sedamdesetih godina, a da je neorealizam na filmu „umro“ početkom pedesetih godina prošloga veka (Cook 2016: 283-285). ${ }^{8}$ Sam Pazolini kao bitnu razliku u odnosu na neorealiste navodi tehniku snimanja: „glavna odlika neorealizma je dug kadar“ i kamera koja miruje, dok ,ja“ uglavnom „snimam kratke dublove“, a „duge kadrove (skoro nikad)“ (Аранђеловић 2004: 50).

bivaju razočarani u radu sa mnom“, jer odbacujem glavni element njihove profesije - „imitiranje prirodnosti“ (Аранђеловић 2004: 50-51).

6 Njegovo shvatanje da „stvarnost ima sebi svojstven način izražavanja“, „da je i sama način izražavanja, koji zahteva, da bi bio opisan, Opštu Semiologiju koja za sada nedostaje“ - dovelo ga je do osobenog određivanja semiologije kao nauke „koja opisuje stvarnost“ (Аранђеловић 2004: 21).

7 On je „sineasta osobene poetike, koja, čini se, još uvek nije do kraja dešifrovana i analizirana“ (isto: 8). Za Andriju Dimitrijevića, teoretičara filma, Pazolinijevo delo „predstavlja ekskluzivni primer filmske umetnosti“; sličnog mišljenja je i reditelj Predrag Delibašić: „Ne mogu da ga poredim ni sa kim, ne mogu da ga smestim ni u jednu fioku“ (isto: 79,80 ).

8 Neorealizam kao termin korišćen je dvadesetih godina prošlog veka „da bi izrazio tadašnje umetničke i književne tendencije po uzoru na nemački termin nova objektivnost (Neue Sachlichkeit)“; u novom značenju, kao oznaka italijanske filmske „škole“, termin se počeo upotrebljavati oko 1943. godine, kada ga je montažer i scenarista Serandrej (Mario Serandrei) upotrebio povodom filma Lukina Viskontija (Luchino Visconti) Opsesija (Feroni 2005: 497). Kao pripadnike italijanskog neorealizma osim Viskontija kao začetnika, Gregor (Ulrich Gregor) i Patalas (Enno Patalas) u svojoj Istoriji filmske umetnosti navode reditelje kao što su Roberto Roselini (Roberto Rossellini), Vitorio de Sika (Vittorio De Sica) i Čezare Cavatini (Cesare Zavattini) i njihove „klasike“: Rim, otvoreni grad (1945), Čistači cipela (1946) i Kradljivci bicikala (1948) (Gregor/Patalas 1998: 154-168). Za Felinija (Federico Fellini), čiji se film Dangube (1953) obično svrstava u neorealizam, nemački autori (isto: 227) pišu da je „preuzeo elemente neorealizma, ali da ih je podvrgao“ „izrazito ličnom preobražaju“, dok Pazolinija ni ne pominju. Felinija, kao i Mikelanđela Antonionija (Michelangelo Antonioni), Dejvid Kuk (David Cook) smešta u „drugu renesansu italijanskog filma“. Što se Pazolinija tiče, ni Kuk ga ne smatra neorealistom: reditelj je neorealizam - prisutan u svega dva filma (Skitnica i Mamma Roma) - napustio radi prenošenja epsko-religiozne ili mitske vizije iskustva u filmovima poput Jevanđelja po Mateju i Kralja Edipa (Cook 2016: 425-434). 
Sa druge strane, Pazolini je od neorealista nasledio rad sa neprofesionalnim glumcima. U filmu Dekameron, osim dva omiljena Pazolinijeva glumca-saradnika, Franka Čitija (Franco Citti) i Nineta Davolija (Ninetto Davoli), većinu uloga igraju neprofesionalci, na primer: fratra koji ispoveda Ser Čapaleta igra slikar Đuzepe Cigaina (Giuseppe Zigaina). Prema Predragu Delibašiću: „Pazolini je uspostavio most sa neorealizmom korišćenjem lica sa ulice, takozvanih naturščika“, ali je razlika u tome što su naturščici kod De Sike i ostalih neorealista „igrali sebe u realističkom kontekstu“, dok su kod Pazolinija, „igrali poznate mitološke likove“ čime je postizao da „istorija i mitologija dobiju realnu dimenziju“ (isto: 81). I na kraju, pošto je najvažnija odlika neorealizma tematika (priča o radničkoj klasi i sirotinji9), Pazolini se zbog filmova baziranim na klasičnim delima, poput Trilogije života, Jevanđelja po Mateju, Kralja Edipa i Medeje, nikako ne može svrstati u neorealiste. Kao dokaz mogu se navesti reči samog Pazolinija: „stvarnost postaje sve neizraženija, i ukoliko kinematografija izražava stvarnost kroz stvarnost, i sama dolazi u opasnost da postane sve manje izražajna, odnosno da bude poput pasivnog ogledala životnih besmislica“10 (isto: 13). „Čak i kada govori o savremenim događajima, kao u svom prvom filmu Accatone (Prosjak)“, piše Moravija, „njegov način izražavanja podseća na modulacije $u$ italijanskim pripovetkama i na freskama iz 13. i 14. veka" (isto: 11). Kao primer mogu se navesti i scene iz „neorealističkog“ filma Mamma Roma u kome inspiraciju za scenu venčanja pronalazi u Tajnim večerama petnaestoga veka, a za scenu umiranja u bolnici u slikama Andree Mantenje (Andrea Mantegna) (Repetto 1998: 63-64). Stoga, ako bi trebalo nekako imenovati Pazolinijevu filmsku poetiku, možda bi se mogao upotrebiti termin za koji Stefano Soči, teoretičar italijanskog filma i masovnih medija, kaže da ga je sam režiser stvorio: „poetičan film“ (cinema di poesia) (Аранђеловић 2004: 77). ${ }^{11}$

Kao prvo zajedničko obeležje Pazolinijeve književne i filmske poetike može se navesti upotreba dijalekta. Svoje prve zbirke poezije Pesme Kazarsi (Poesie a Casarsa, 1942) i Najbolje od mladosti (La meglio gioventù, 1954) piše na furlanskom i venecijanskom dijalektu.

9 Novi realizam, kao opozicija kulturnim idealima fašizma, impulse je vukao iz Verginog (Giovanni Verga) verizma sa ciljem da se film „približi“ „konkretnoj svakodnevnoj stvarnosti“ i bude „ogledalo“ „socijalnog ustrojstva“ (Gregor/Patalas 1998: 159). Čezare Cavatini je tražio da se „građa“ uzima sa ulice i snima na originalnim lokacijama, kako bi se uspostavio direktan kontakt sa savremenom društvenom stvarnošću (Cook 2016: 278). Širenjem novog načina prikazivanja života i afirmacijom neorealističkog filma, nastaje, „gotovo spontano“, „glas naroda koji postaje protagonista i priča o samom sebi“ (Feroni 2005: 496).

10 Kurzivom istakao P. M.

11 Videti i: Pasolini 2008: 1461-1488; Luzzi 2014: 70-85. 
U romanima kao što su Ragazzi di vita (1955), prevedeni kao Iskusni momci / Mladi uličari, i Una vita violenta (1959), preveden kao Silovit život / Žestok život, koristi rimski dijalekat. U filmu Dekameron Pazolinijevi likovi govore napolitanskim dijalektom, između ostalog i zbog toga što se priča o najboljem učeniku slikara Đota (Giotto di Bondone) odvija na jugu Italije. Na primer, posle epizode sa Andreučom iz Peruđe (II, 5), starac okupljenoj masi na napolitanskom pripoveda II novelu Devetog dana o Izabeti i Uzimbaldi. Pazolini je, pišući poeziju na dijalektu, dospeo u kontradiktornu poziciju: autorova poezija umesto da bude dostupna širim slojevima društva, hermetična je i „nečitljiva“. Poetičko objašnjenje ovog paradoksa ponudio je sam Pazolini: ,autor kao što sam ja, koji je bio dvorska luda, odbija da postane luda široke mase“, da bude „naprosto komunikativan“ i da „zaboravi teška pravila izražajnosti“12 (Аранђеловић 2004: 14). Lako čitljiva, dostupna ili komunikativna umetnička dela nisu umetnost, jer postaju roba što se proizvodi na fabričkoj traci. U pozadini ovog stava leži Pazolinijevo uverenje da umetnost, bilo književna bilo filmska, ne sme da bude „potrošačka roba“ (Аранђеловић 2004: 14).13

Druga odlika književnog i filmskog stvaralaštva, svakako, jeste „eksperimentalni nemir“ - „Pazolini kao da je opsednut neobuzdanim porivom da odgovori i progovori, da se na svaki mogući način izrazi“ (Feroni 2005: 563). Stoga, on poeziju ne piše samo na dijalektu, nego i na italijanskom jeziku, kao u zbirci pesama Gramšijev pepeo (Le ceneri di Gramsci, 1957), u kojoj „prema Paskolijevom obrascu“ koristi klasičnu formu, tercinu, koju je još u srednjem veku ustanovio Dante (Dante Alighieri) (isto: 564). Kao pripovedač, na primer, u romanu Iskusni momci ne samo što ne koristi tradicionalnu linearnu naraciju ili psihološki produbljene likove, nego upotrebljava specifičnu pripovednu strategiju - doživljeni govor. On prenosi misli i osećanja svojih likova-probisveta bez naznake da su u pitanju stavovi junaka, a ne naratora, kao na primer:

prinudni smeštaj [Kudravog] ionako se nije mogao nazvati kućom; svejedno mu je bilo da li će se vratiti ili neće, da li će prespavati tamo ili na nekoj klupi u parku. Strinu ionako nije mogao očima da vidi, kao, uostalom, ni njenog sina Alduča. Stric je bio pijanica koji je po ceo dan gnjavio sve oko sebe (Pazolini 2015: 63).

Prema scenaristi Čeramiju (Vincenzo Cerami), Pazolinijev „radikalan i prividno neknjiževni izbor, kritika onoga doba pogrešno je razumela i površno procenila“. „Pokušajem da se bez autorovog po-

12 Kurzivom istakao P. M.

13 Misliti o umetnosti kao o robi, da je uopšte moguće da se umetnost i roba nađu „u jednom istom telu“, za Pazolinija znači napraviti od umetničkog dela monstruma, sirenu, hermafrodita (Аранђеловић 2004: 21). 
sredovanja čuje glas klase koja je genetski isključena iz književnosti, Pazolini je postavio temelje“ „eksperimentalnog pisma“ (Čerami 2015: 5). Čeramijeva pohvalna ocena o eksperimentalnom pismu svakako je preterana. Zanimljivije je to što je Pazolini upotrebom doživljenog govora, kao i sa „nečitljivim“ dijalektom, opet dospeo u kontradiktoran položaj. Upotrebom doživljenog govora, umetnik predstavlja unutrašnji svet junaka-probisveta koji taj svet nemaju. A oni ga nemaju ne zbog toga što nemaju kapacitete ili kvalitete za izgradnju unutrašnjeg sveta, već zbog pripadnosti klasi koja je od jutra do sutra u potrazi za hlebom, i stoga u nemogućnosti da neguje sopstvenu ličnost.

Kada je o Pazolinijevim eksperimentima na filmu reč, dovoljno je navesti kratak presek stvaralaštva iz Kukove istorije filma: od beskompromisnih „neorealističkih“ studija života u rimskim predgrađima u filmovima Skitnica i Mamma Roma, preko veličanstvenog pseudodokumentarca Jevanđelje po Mateju, urađenog u stilu cinéma vérité, Pazolini se u filmovima Ptičurine i ptičice, Kralj Edip i Teorema okrenuo alegoriji i mitu, da bi se u poslednjem filmu Salo ili 120 dana Sodome poslužio tehnikom osavremenjivanja bizarnog dela Markiza de Sada (Marquis de Sade) (Cook 2016: 434-435).

Ozloglašeni film Salo ili 120 dana Sodome, svakako, upućuje na skandal, šok, treću i možda najpoznatiju odliku Pazolinijevog filmskog stvaralaštva, koja se prvenstveno odnosi na putenost, obnažena muška i ženska tela i eksplicitnu seksualnost. Zbog svog prvog romana Iskusni momci Pazolini je bio „optužen za 'pornografiju'“; proces se završio „oslobađajućom presudom“ (Feroni 2005: 565). ${ }^{14}$ Prema Čeramiju (2015: 10-11), roman je „uprkos svojoj književnoj vrednosti“ „sablaznio onu dušebrižničku malograđansku Italiju“ koja „vrvi od geometara, lovaca na priznanja i 'plavušica u gondolama'“. Film Dekameron „vrvi“ od kadrova obnaženih tela i scena eksplicitne erotike. Prema Feroniju (Giulio Ferroni), Pazolini je iz želje za skandalom, naročito u poslednjoj fazi, „posegnuo za snažnijim provokacijama“, te je „napadajući društvo i buržoaski potrošački mentalitet“ i sam krenuo putem degradacije; prema oceni Feronija, zadržavajući se „na spoljašnjoj retorici seksualnosti“, Pazolini je „banalizovao krupne psihološke i socijalne probleme“ (Feroni 2005: 568-569). Sasvim drugačiji stav iznosi Antonela Pivac pri analizi likova iz dramskog opusa: svi oni „u jednom trenutku odustaju od lagodnog konformizma i istupaju u borbi za priznavanje vlastite osobnosti“. Stoga je u Pazolinijevom teatru „scandalo na vrhu piramide lingvističkih sklopova koje simboliziraju istupanje i transgresivnost" (Pivac 2012: 66).

14 To je bio drugi po redu od ukupno 33 sudska procesa koje je Pazolini doživeo (Feroni 2005: 565). 
Da je Antonela Pivac bliža tačnijem odgovoru, može se videti stavljanjem Pazolinijevog dela u širi kontekst (neo)avangardnih pokreta u književnosti i umetnosti iz prve polovine dvadesetog veka. Taktike šoka predstavljaju legitimno sredstvo avangardne umetnosti od samih njenih početaka. U krajnjem slučaju, još je preteča simbolista, Šarl Bodler (Charles Baudelaire), polovinom devetnaestoga veka nastojao da épater les bourgeois (šokira buržuje), a zbog zbirke Cveće zla završio na sudu. Granice šoka, šta se sme prikazivati, a šta ne, šta izaziva skandal, a šta ne, slabile su protokom vremena: dovoljno je uporediti Bodlerov vokabular sa rečnikom Kralja Ibija Alfreda Žarija (Alfred Jarry) ${ }^{15}$. Stoga ne čudi da početkom sedamdesetih godina prošlog veka nastaju još kontroverznija dela poput filma Salo ili 120 dana Sodome ili performansa Marine Abramović Ritam Nula koji je umetnica napravila na jugu Italije, u Napulju, godinu-dve pre Pazolinijevog poslednjeg filmskog ostvarenja.

\section{Eros}

Pri tumačenju i vrednovanju erotike u Pazolinijevom filmskom opusu, trebalo bi voditi računa i o stavovima samog autora po pitanju odnosa seksualnosti i života, kao i seksualnosti i umetnosti. Pazolini nije bio pristalica seksualne revolucije koja je zahvatila zapadni svet šezdesetih i sedamdesetih godina prošlog milenijuma. U ovoj slobodi on nije video oslobađanje već neohedonističku ideologiju - „sastavni deo potrošačkog mentaliteta“. Naime, za umetnika seksualna revolucija predstavlja gubitak vrednosti: one vrednosti koje su bile „realne u seoskom i paleo-industrijskom društvu“ pretvorene su u „fraze i teror“ (Аранђеловић 2004: 15). Kada je o odnosu umetnosti i seksualnosti reč, Pazolini piše:

Umetnici moraju da stvore (a kritika odozdo da podrži i demokrate podupru) ekstremistička dela koja ne mogu da prihvate čak ni najliberalnija stanovišta na nivou države (isto: 16).

15 Počeci avangardne umetnosti u drami vezuju se za premijeru Žarijevog Kralja Ibija 11. decembra 1896. godine, a o skandalu koji je izazvala predstava svedoči Jejtsova (William Butler Yeats) reakcija: „Idem na prvu predstavu Kralja Ibija od Alfreda Žarija.“ „Gledaoci prete pesnicama jedni drugima“ i „česte su tuče posle predstave“. „Kažem, posle Stefana Malarmea, posle Pola Verlena, posle Gistava Moroa, posle Pivija de Šavana, posle naših sopstvenih reakcija [..., šta je još moguće? Posle nas surovi bog“ (Selenić 2002: 21-22). Analizu Žarijevog komada, ali i drama i hepeninga Apolinera (Guillaume Apollinaire), dadaista i nadrealista u kojima se šok i skandal konceptualizuju kao „užasno lepo“ videti u: Selenić 2002: 19-41. 
Time bi se „raskrinkali čisto ekonomski krajnji ciljevi, poput jasno određene seksualne liberalizacije (sloboda ljubavnog para kao potrošača)“ (isto).

Ako se ima na umu da, prema Pazoliniju, „državna tolerancija toleriše komercijalna pornografska, odnosno prosta dela, ali stremi ka netoleranciji umetničkih dela u kojima erotski elementi uvek imaju kulturni i politički smisao" (isto: 16), jasno je u kom pravcu treba tumačiti Pazolinijevu književnu ili filmsku upotrebu seksualnosti. Kako obnaženost i erotika ne bi postale jeftina pornografija, one uvek moraju imati i neki višak smisla u delu, u krajnjem slučaju, čistu provokaciju, šok ili skandal. Čini se da je nedostatak kulturno-političkog smisla erotskih delova "dve autobiografske mladalačke priče“ (Feroni 2005: 567), Grešna dela / Bludne radnje (Atti impuri) i Amado mio - bio glavni razlog zašto ih nije za života objavio; u predgovoru pisac ističe da nije bio siguran „da li su veoma škakljive teme“ „dovoljno objektivizovane“ (Pazolini 1984: 7).

Kao dobra ilustracija da eros u umetničkom delu mora posedovati višak smisla može poslužiti i sam Đovani Bokačo. Prema Repetiju (Repetto 1998: 119), Pazolini je posle Medeje, zasnovane na grčkoj tragediji, želeo da snimi drugačiji film. Razmišljajući o filmu u kome bi slavio radost života i vođenje ljubavi, reditelju je na pamet odmah pao Bokačo. Izbor Bokača, svakako, nije slučajan ako se ima na umu da pisac Dekamerona „i danas u svesti mnogih postoji kao 'vešti pripovedač' zanimljivih, vrlo često lascivnih, pa samim i tim i duhovitih pričica bez ikakvog značaja“; njega i dalje prate atributi „frivolnosti““ i „nemoralnosti“ nastali „u doba romantičarsko-pozitivističke kritike“ (Milinković 2011: 6, 5). Sećanja na predavanja profesora Aleksandra Ilića koja sam slušao školske 1999/2000. godine poslužiće za analizu erosa u Bokačovom Dekameronu.

Profesor Ilić je u okviru svog kursa Renesansna proza i poetika ${ }^{16}$ na drugoj godini studija Opšte književnosti i teorije književnosti, predavao o Dekameronu, o romanu Gargantua i Pantagruel Fransoa Rablea i o Servantesovom romanu Don Kihot. Pri analizi Dekamerona,

16 Profesor Ilić je o Bokaču predavao pozivajući se, između ostalih, i na Bogdana Suhodolskog (Bogdan Suchodolski). Poljski filozof u Modernoj filozofiji čoveka (Suhodolski 1972: 125-128) o Bokaču piše u okviru poglavlja „Rađanje i nade humanizma“. Italijanisti, međutim, Bokača smatraju srednjovekovnim piscem, na primer, Franko Čale i Mate Zorić u odeljku IV toma Povijesti svijetske književnosti, posvećenog italijanskoj književnosti, o Danteu, Petrarki i Bokaču govore kao o velikoj trijadi trecenta (četrnaestog veka), a povodom Dekamerona o „nagoveštajima renesansnih shvatanja“ (Čale/Matić1973: 46). Književni istoričar i filolog, i najznačajniji proučavalac Bokača, Vitore Branka (Vittore Branca), naslovom svoje studije Srednjovekovni Bokačo (Boccaccio mediavale) jasno precizira kojoj epohi pripada Bokačo. Videti i Milinković 2011: 18, 56-57, 96-97; Guglielmino/Grosser 1988: 1026. 
profesor je kao najbitnije Bokačove „četiri linije“ izdvojio: nov koncept ljubavi, kritiku crkve, kritiku predrasuda u mišljenju i razvoj moderne novele. Za problem koji pokušavam ovde da rasvetlim od najveće su koristi profesorove analize koncepta ljubavi u Dekameronu koja nije uvek vesela kao u priči o Mazetu (III, 1). Pri analizi novele o nesrećnoj ljubavi Gviskarda i Gizmonde (IV, 1), koji tragično okončavaju svoj život poput drugih parova ljubavnika (Piram i Tizba, Paolo i Frančeska, Romeo i Julija...), Aleksandar Ilić je skrenuo pažnju na drugačiji koncept plemenitosti koji iznosi glavna junakinja: „Pogledaj malo sve svoje plemiće i ispitaj njihove vrline“, „a potom pogledaj Guiskarda; prosudiš li nepristrasno i bez mržnje, priznat ćeš da je najplementiji, a svi ostali da su prostaci“ (Boccaccio 1991: 235). Ideju da plemenitost ne počiva u plemenitom poreklu već u vrlini - pre Bokača uneli su u italijansku književnost pesnici škole „slatkog novog stila“, kojima pripada i mladi Dante, a pre njih - Bruneto Latini (Guglielmino/Grosser 1988: 105-110, 496). Stoga je profesor Ilić svoje tumačenje pomenute novele usmerio ne toliko na nov koncept plemenitosti, koliko na kritiku predrasuda u mišljenju oličenih u figuri oca, u knezu Tankrediju. Iz dugog Gizmondinog monologa kojim junakinja pravda svoj postupak, Aleksandar Ilić je kao ključnu izdvojio sledeću rečenicu: „Više cijeniš javno mnijenje negoli istinu“, pa kažeš da se „ne bi ljutio da sam izabrala čovjeka plemenita roda“ (Boccaccio 1991: 234). ${ }^{17}$ Za profesora je kritika mnjenja i predrasuda predstavljala ključne reči humanizma i renesanse. Osim toga, Aleksandar Ilić je u junakinjinim rečima: „Nisam Guiskarda slučajno odabrala, kao što to mnoge rade, već nakon zrela premišljanja izabrala ga međ svim ostalima“" (isto) - prepoznao univerzalne vrednosti odgovornosti i slobode izbora. Može se zaključiti da se novela o nesrećnim ljubavnicima bez viška značenja - nov koncept plemenitosti, kritika predrasuda u mišljenju, ideje slobode i odgovornosti - ne bi ni po čemu razlikovala od brojnih melodramskih tekstova slične tematike. Time se potvrđuje teza, ne samo Pazolinijeva, da erotski elementi imaju ili moraju imati i kulturni i politički smisao, kako se ne bi sveli na sentimentalnost ${ }^{18}$ ili na lascivnost, kao u noveli o Mazetu iz Lamporekja.

„Ljubav je jača od vas i od mene“, tako kaže Gizmonda (isto: 233). Profesor Ilić je isticao da u Dekameronu Bokačo donosi nov koncept ljubavi u odnosu na srednji vek, čiji je lažni asketizam u čulnoj ljubavi bez duhovnog elementa gledao raskalašnost, te da je pisac stao $u$

17 Kurzivom istakao P. M.

18 Za Auerbaha (Erich Auerbach) novele poput priče o ljubavi Gizmonde i Gviskarda suviše su „pustolovne i bajkovite, da bi bile stvarne, suviše lišene čari i suviše retorične, da bi bile bajkovite, i suviše sentimentalne, da bi bile tragične“ (Milinković 2011: 119). 
odbranu telesne ljubavi kao prirodne, a što je profesor pokazao tumačenjem nedovršene novele o sinu Filipa Baldučija. ${ }^{19}$ Sina je otac godinama držao „pod staklenim zvonom“ i odgajao u strogom asketskom duhu. Kada sin prvi put ugleda gospe u svom životu, otac mu kaže da su to „guske“, napast koju ne treba gledati. Ali, pošto je priroda jača od razuma, mladić ocu odgovora na sledeći način: „lepše su od naslikanih anđela što ste mi ih više puta pokazivali“ (Boccaccio 1991: 227). Eros je u Dekameronu predstavljen kao prirodna sila kojoj se ne mogu odupreti čak ni monasi, a od brojnih varijacija ove teme kao najpoznatije izdvajaju se prva i poslednja novela ispričane Trećeg dana.

Ako se porede novela o Mazetu iz Lamporekja i novela o Alibehi monahu Rustiku (III, 10), jasno je zašto Bokačo nije samo frivolni pisac golicavih pričica. Priča o Mazetu, koju je profesor Ilić tumačio, a Pazolini preneo na filmsko platno - jasnije od novele o Alibeh pokazuje da u umetničkom delu „erotski elementi“ imaju „kulturni i politički smisao“. Da se novela ne završava peripetijom i poentom na kraju, priča bi zaista bila samo lascivna, čak na granici dobrog ukusa. Obrt, kao što je poznato, predstavlja čudo koje se desilo u manasti$\mathrm{ru}$ - gluvonemi mladić Mazeto je progovorio. Prema profesorovom tumačenju, Bokačo je ovim obrtom na kraju novele kritikovao crkvenu instituciju čuda. Na isti način, kao kritiku crkve, profesor je tumačio i obrt u noveli o Čapeletu - to što „najgori čovjek što ga je ikad svijet ugledao" (Boccaccio 1991: 36) na kraju biva proglašen za sveca, dovodi u pitanje crkvenu instituciju svetitelja. ${ }^{20}$ Međutim, finalna Bokačova ironija nalazi se u poenti na kraju novele. Naime, pisac kaže da nam ona „dokazuje kako je Krist milostiv prema onima koji mu iznad krune rogove nabijaju“ (isto: 164). Mladić koji je otišao iz svog sela sa sekirom na ramenu, vraća se u rodno mesto bogat, pošto nije morao da vodi računa o opatićima koje je ostavio iza sebe.

Profesor nam je pri tumačenju novele o Mazetu skrenuo pažnju i na dva postupka karakteristična za Bokača kao pripovedača - detalj i (duhovitu) aluziju (erotskog sadržaja). Kao primer detalja, Ilić je naveo scenu kada opatice treba prvi put da „poznaju“ Mazeta - „ona ga laskavim kretnjama uze za ruku, i dok se on blesavo smijao, uvede u kolibicu“ (Boccacccio 1991: 162). ${ }^{21}$ Duhoviti detalj, Mazetov blesavi

19 Uporediti sa: Ljubav je „prirodna pojava - pa samim tim i racionalno uređena kao što to priroda, pa i čovekova priroda jeste“ (Milinković 2011: 50). Druge smisaone implikacije (parodija mizogine teme, odbrana sopstvene književnosti, ali i poezije uopšte) ove „polu-novele“, videti u: Milinković 2011: 49-52.

20 Prve tri novele Prvog dana o ser Čapeletu, Jevrejinu Avramu i Jevrejinu Melkisedeku predstavljaju „triptih posvećen reinterpretaciji tema zvanične crkvene kulture“ (Milinković 2011: 109).

21 Kurzivom istakao P. M. 
smeh, predstavlja kritiku predrasude o gluvonemim ljudima kao blesavim, manje inteligentnim od „normalnih“; duhovitost je u tome što Mazeto koji se pretvara da je gluvonem - „igra na tu kartu“, pretvara se da je blesav i da ništa ne razume. Zbog viška značenja erotskih elemenata - kritika crkve i kritika predrasuda u mišljenju - novela o Mazetu nije samo lascivna i duhovita pričica bez ikakvog značaja i značenja.

Kao primer duhovitih aluzija iz novele, Aleksandar Ilić je navodio Nutove reči: „Obrađivao sam njihov velik i lijep vrt“, i „dok sam obrađivao vrt, jedna mi govori: 'Posadi ovo ovdje'. Druga: 'Ono usadi tamo'. Treća bi mi uzela motiku iz ruke i rekla: 'Ne valja ovo ovako!' (isto: 160)." Upravo te reči podstiču Mazeta da krene put manastira. A dok ispred vrata čeka da nastojnik odluči da li će ga „zaposliti“, Mazeto se u sebi misli: „Ako me uzmete, tako ću vam vrt obraditi kao što ga nitko nije obradio“ (isto: 160-161). Najpoznatija aluzija u Dekameronu - pored „vraćanja đavola u pakao“ iz novele o Alibeh - svakako jeste „slavuj“ (usignolo) iz priče o ljubavi Katerine i Rikarda (V, 4). Bokačo je prvobitno značenje slavujeve pesme kao izliva plemenite ljubavi, a koje je poteklo iz dvorske tradicije, parodijski promenio i prilagodio svetu koji prepoznaje samo materijalne i konkretne vrednosti: slavuj će svojom pesmom uspavati Katerinu, Rikardo će više puta terati slavuja da zapeva, pa će morati da se oženi Katerinom i da stavi slavuja u svoj kavez (Milinković 2011: 132-133). Način na koji je Pazolini ekranizovao ovu novelu dovodi do zaključne odlike njegove poetike, koja se može odrediti kao semiologija života.

Pazolinijeva semiologija života podrazumeva neuvijen odnos prema stvarnosti, večito traganje za izrazom, suočavanje sa svetom i svakodnevicom, kao i shvatanje kulture kao „neprekidnog prisustva u svetu“ (Feroni 2005: 563). Stavovi koji ilustruju ovaj segment poetike su: „Koristio sam dijalekt ne iz ljubavi prema dokumentu već iz ljubavi prema stvarnosti“; film „predstavlja eksploziju“ moje „ljubavi prema realnosti“ (Аранђеловић 2004: 56). Ako se ima na umu stav Kontinija (Gianfranco Contini) da je usvajanje lokalog jezika „neustrašiva“ „izjava ljubavi“ prema stvarnom svetu (Čerami 2015: 6), čini se da Pazolinijeva upotreba dijalekta, eksperimenti sa formama, stilovima i postupcima, skandali i seksualna retorika, te njegovo nastojanje da se direktno i neuvijeno suoči sa svetom i svakodnevicom, izviru iz njegove vitalnosti i ljubavi prema životu i stvarnosti, iz semiologije čiji je naučni zadatak, po umetnikovom shvatanju, opis stvarnosti. Stoga ce Pazolini pri ekranizaciji priče o Katerini i Rikardu u krupnom kadru vizuelizovati i eksplicitno publici predstaviti Katerinu sa slavujem u ruci.

Analiza erosa u Dekameronu - zasnovana na tumačenjima profesora Ilića - trebalo je da ilustruje Pazolinijevu tezu da „erotski elementi 
uvek imaju kulturni i politički smisao“, te da uputi na Pazolinijevu reintepretaciju Bokačovog koncepta ljubavi. Naravno da je Bokačovo shvatanje ljubavi kompleksnije i da ga treba sagledavati u kontekstu njegovih prethodnika, Dantea i srednjovekovne književnosti i kulture. Ili kako to Snežana Milinković piše: Bokačo kao pisac „govori 'u ime i u znaku ljubavi'“ „držeći da je baš 'ljubav' jedini i pravi demarkacioni znak i apsolutni simbol književnosti u sistemu tekstova ondašnje kulture“ (Milinković 2011: 15). ${ }^{22}$ Pazolini je ekranizacijom Bokačovih golicavih novela slavio čulnu prirodu ljubavi u njenom „prirodnom“, „ruralnom“ okruženju, izvan (malo)građanskog hedonističkog kruga, koji je kritikovao u filmu Teorema, snimljenom tri godine pre Dekamerona (Repetto 1998: 116, 118). Čini se da je prilagođavanjem kontekstu svoga doba i suprotstavljajući se ondašnjoj neohedonističkoj ideologiji otvorenom erotikom, Pazolini sačuvao u izvornom obliku Bokačovu ideju o telesnoj strasti kao prirodnoj.

\section{Adaptacija}

Imajući u vidu poetičke elemente zajedničke Pazolinijevim književnim i filmskim radovima, film Dekameron se može „čitati“ i kao adaptacija slavnog Bokačovog dela. Kada se govori o adaptaciji, obično se misli na filmsku ekranizaciju klasika, prvenstveno romana svetske književnosti. Hačn (Linda Hutcehon) u Teoriji adaptacije (A Theory of Adaptation) piše da se duža pripovedna dela prilikom adaptiranja nužno skraćaju zbog prilagođavanja prirodi filmskog medija i prosečnom trajanju bioskopske projekcije od oko dva sata (Hutcheon 2006: 36). Retki su primeri filmova koji traju neuporedivo duže, kao što je Dekalog: Deset zapovesti (1989) Kišlovskog (Krzysztof Kieślowski) u trajanju od deset časova ili Lancmanov (Claude Lanzmann) dokumentarac Holokaust (Shoah) iz 1985. godine, koji ispunjava devet sati projekcije. ${ }^{23}$ Pazolini, iz pomenutih razloga, nije ekranizovao svih sto novela, već je napravio sledeći izbor: Andreučo iz Peruđe (II, 5), Mazeto iz Lamporekja (III, 1), Peronela i bure (VII, 2), Čapeleto (I, 1), slavujev poj (V, 4), Lizabetin bosiljak (IV, 5), začarana kobila (IX, 10), dvojica Siježana (VII, 10) i priča o Đotu, preciznije, priča o „najboljem Đotovom učeniku“, kako se kaže u filmu, koga igra sam Pjer Paolo Pazolini. Osim skraćivanja i izbora novela, Pazolinijeva kreativna

22 Više o književnom i kulturnom kontekstu koji prethodi Dekameronu videti u: Milinković 2011: 9-15.

23 Ovo temporalno ograničenje važi i za dela koja se izvode na daskama koje život znače. Predstave koje traju devet sati poput Mahabharate (1985) Pitera Bruka (Piter Brook) ili 24 časa kao Olimp Jana Fabra (Jan Fabre), koji je otvorio 51. Bitef - predstavljaju izuzetke, a ne pravilo. 
adaptacija Bokača uključuje promenu noseće priče Dekamerona i umetanje elaborirane epizode o učeniku slikara Đota.

U zavisnosti od toga kolike su i kakve izmene napravljene u odnosu na originalni tekst, teoretičari uglavnom razlikuju tri vrste adaptacije. Na primer, kod Dadlija Endrua (Dudley Andrew) to su sledeće: 1) pozajmljivanje - intertekstualno „spontano preuzimanje priča, ideja i situacija“, do čega neizbežno dolazi pri „bilo kom stvaralačkom činu“; 2) ukrštanje - situacija kada režiseri koriste „različite filmske metode da bi - što je moguće vernije - predstavili svet i strukturu originala“; 3) transformacija - ovo je adaptacija koja „koristi sav potencijal kinematografskih tehnika i materijala“ tako da "ostane verna originalu“ i da istovremeno napravi „nešto novo“",u novom mediju“ (Abot 2009: 186-187). Teoretičari adaptacije, nažalost, koriste različite termine da bi označili iste ili slične fenomene. Prema Brajanu Makfarlanu (Brian McFarlane), Džefri Vagner (Geoffrey Wagner) u knjizi Roman i film (The Novel and the Cinema) iz 1975. godine razlikuje: 1) transpozici$j u$ - roman je direktno prebačen na platno sa minimumom promena; 2) komentar - originalni tekst od koga se polazi pretrpeo je značajne izmene; 3) analogiju - potpuno odvajanje od polaznog teksta, kako bi se napravilo sasvim novo umetničko delo. ${ }^{24}$ Za razliku od tripartitnog modela Endrua i Vangera, Džuli Sanders (Julie Sanders) u knjizi Adaptacija i aproprijacija (Adaptation and appropriation) predlaže podelu sadržanu u samom naslovu. Autorka, nažalost, ne samo što odbija da precizno definiše termine, već upada u kontradikciju - iako na pitanje vernosti originalu prezrivo odbija da odgovori, kao ključnu razliku između adaptacije i apropijacije, navodi upravo kategoriju vernosti (Sanders 2006: 2-41).

Na osnovu klasifikacija Endrua, Vagnera, ali i Sandersove, može se zaključiti da se kao ključna kategorija pri ispitivanju adaptacije pojavljuje ne baš uvek jasna i precizno određena kategorija vernosti. H. Porter Abot (H. Porter Abbott) smatra da kritičar pre nego što vrednuje neko delo na osnovu vernosti originalu, treba prethodno da utvrdi „da li je vernost originalu uopšte bila cilj“. Ako utvrdi da nije, onda bi o delu morao da „sudi na osnovu drugih kriterijuma”, koji mogu, ali i ne moraju podrazumevati poređenje sa originalom (Abot 2008: 187).

24 Makfarlan, međutim, pogrešno zaključuje da je Vagnerova podela istovetna sa tipologijom Dadlija Endrua (McFarlane 2009: 389). Naime, jedino se Endruovo ukrštanje i Vagnerova transpozicija mogu izjednačiti: u pitanju je adaptacija koja je verna originalu sa minimumom promena hipoteksta. Prva vrsta adaptacije o kojoj govori Endru, intertekstualno i kreativno pozajmljivanje ne postoji u Vagnerovoj tipologiji, dok se treća Endruova kategorija, transformacija, koja podrazumeva i vernost i novo delo, ne može bez ostatka izjednačiti ni sa komentarom (značajne izmene) ni sa analogijom (sasvim novo umetničko delo) Džefrija Vagnera. 
Poređenje sa originalom je problem koji razmatra i Linda Hačn, i to iz ugla recepcije. Odgovor na pitanje „kako“ se adaptira, ona traži u publici - da li je recipijent upoznat sa tekstom koji se adaptira ili nije, i smatra da je adaptacija dobra, ako se s podjednakim uspehom obraća obema vrstama publike, onoj koja poznaje delo i onoj kojoj je originalni tekst nepoznat (Hutcheon 2006: 113-140).

Kao ilustracija autorkine teze može poslužiti film Vudija Alena (Woody Allen) Nesrećna Džasmin (2013). Jedni su ga doživeli kao nesrećnu, gotovo tragičnu priču o glavnoj junakinji, dok su drugi, koji su prepoznali reference na Tramvaj zvani želja (1951), film Elije Kazana (Elia Kazan), uživali u Alenovom delu kao urnebesnoj parodiji. ${ }^{25}$ Isto pravilo važi i za Pazolinijev Dekameron. Naravno da će publika koja poznaje Bokačovo delo drugačije „,̌itati“ i razumeti smisao Pazolinijevog ostvarenja. Za Lindu Hačn, pitanje ko je „bolje“, „pravilnije“ razumeo film, nije toliko relevantno. Na pitanje uspešnosti Pazolinijevog dela, u smislu vernosti Bokačovom originalu - ne mora se odgovarati jedino na nivou horizonta očekivanja publike i iz ugla teorije recepcije, kako to „demokratično“ predlaže kanadska teoretičarka. Problemu vernosti može se pristupiti jednostavnije, prostim poređenjem originala i adaptacije, a uz pomoć kategorija Dadlija Endrua.

Kao primer kreativnog pozajmljivanja, spontanog preuzimanja ideja, može se uzeti vizuelno predstavljanje Đotovog učenika koji je, kako to primećuje Cigaina (Zigaina 1991: 180), u većini scena obučen kao Velaskezov (Diego Velázquez) Vulkan. Španski slikar je na platnu Vulkanova kovačnica (1630) predstavio trenutak kada „Apolon, bog Sunca“ dolazi da obavesti Vulkana da ga je „žena Venera prevarila $s$ Marsom, bogom rata“, kome je upravo iskovao oklop (Đorđi 2012: 62). Pošto je tema Velaskezove slike preljuba, prevara i izdaja, postavlja se pitanje smisla ove vizuelne pozjamice, budući da Vulkanova kovačnica stilski i sadržinski odudara od Đotovog likovnog stvaralaštva, a tematski i od Pazolinijevih kadrova o slikaru, u kojima su predstavljene prepreke na koje Đotov učenik nailazi pri oslikavanju crkve Santa Kjara. Prema Cigaini (Zigaina 1991: 180), pozajmica od Velaskeza svedoči o uticaju muzeja Prado, ali i mitske figure kovača, na samog Pazolinija. Pazolini je spontano iskoristio sećanje na ovu sliku, kako bi vizuelno obogatio i dekorisao pomenute kadrove, te se, na prvi pogled, značenje ove vizuelne pozajmice iscrpljuje u njenoj dekorativnoj funkciji.

Prema Repetu, postupak pravljenja kadrova ugledanjem na likovna dela predstavlja opšte mesto u radovima o Pazolinijevom stvaralaštvu. Već je pomenuto da je i u „neorealističkim“ filmovima, Skitnica i Mamma Roma, režiser kao modele koristio freske iz trinaestog i

25 Analizu filma Vudija Alena kao pastiša filma Tramvaj zvani želja videti u: Mirčetić 2017. 
četrnaestog veka, Tajne večere petnaestoga veka i slike Andree Mantenje. Ovaj postupak Antonino Repeto imenuje terminom „likovni citat" ("citazione figurativa") (Repetto 1998: 143) ${ }^{26}$ Endruovo spontano pozajmljivanje, kao podvrsta adaptacije, odgovora Pazolinijevim citatima. Iako citat i adaptacija nemaju isto značenje, iz ove terminološke zbrke može se zaključiti da je sam termin adaptacija višesmislen i da se više ne iscrpljuje u ,školskoj“ definiciji kao prenos dela u drugi žanr ili medij.

Kada je o druge dve Endruove kategorije reč, na pitanje da li film Dekameron spada u ukrštanje (vernost) ili transformaciju (i vernost i novina) - na prvi pogled - lako je odgovoriti. Pošto su umesto Bokačove noseće priče o sedam devojaka i tri mladića kao okviri postavljene dve priče, priča o Čapeletu i priča o „Đotu“, Pazolini je značajno izmenio tekst i uneo novine i stoga bi film Dekameron trebalo svrstati u transformaciju. No, problem nije tako jednostavan kao što se čini. Krupna promena u hipotekstu ne mora nužno značiti da je automatski napravljeno novo umetničko delo. Na primer, Viskonti je pri adaptaciji novele Smrt u Veneciji izmenio „profesiju“ glavnog junaka. Prema Lindi Hačn, Tomas Man je od samog početka novele insistirao na estetičkoj i psihološkoj dvosmislenosti Ašenbaha kao pisca, kako bi dočarao unutrašnju motivaciju protagoniste. Viskonti je promenio Ašenbahovu vokaciju - umesto pisca, on na filmu postaje kompozitor. Prema autorki ova promena je nastala radi prilagođavanja novom mediju. Budući da je na filmu vizuelno-auditivnim sredstvima lakše predstaviti muzičko stvaralašto od cerebralnih procesa, muzika će uverljivije dočarati Ašenbahovu unutrašnju motivaciju i dvosmislenost nego predočavanje junakovog toka svesti (Hutcheon 2006: 44).

Moguće je da je Pazolini iz istog razloga - prilagođavanja novom mediju, a sa ciljem da sačuva osnovnu ideju Bokačove noseće priče promenio okvir. Lakše je i ubedljivije na filmu vizuelno predstaviti likovno stvaralaštvo „Đota“ od usmenog pripovedanja „vesele družine“. Štaviše, moglo bi se tvrditi da je upravo radi vernosti originalu, suštinskoj ideji koju nosi noseća priča - Pazolini napravio ovako značajnu promenu. Ako je tačno da je Pazolini putem (spoljašnje, fabularne) promene sačuvao Bokača od (unutrašnje, značenjske) promene, onda bi njegov film spadao u ukrštanje Dadlija Endrua.

Problem vernosti, da li je Pazolinijev Dekameron ukrštanje ili transformacija, može se sagledati iz ugla ekranizacije svake novele ponaosob, a kao primer može da posluži priča o Peroneli (VII, 2). Njena tema, kao i ostalih novela iz Sedmoga dana jeste prevareni muž. Peronelin muž se iznenada vraća kući i ona u panici sakriva ljubavni-

26 Primere likovnih, ali i filmskih i književnih citata videti u: Repetto 1998: 143-151. 
ka Đanela u bure. Kada joj muž kaže da je prodao bure, ona mu odgovara da ga je i ona prodala i to čoveku koji je sakriven u buretu. Novela se završava tako što Đanelo naređuje mužu da mu istruže bure koje potom odnosi kući. U filmu, pri kraju scene muž se u buretu, dok ga struže, smeje „kao lud na brašno“. Iako smeh ne postoji u Bokačovom tekstu i predstavlja Pazolinijevu intervenciju, reditelj ovom novinom zapravo aktivira značenje same novele.

Naime, u ovoj priči, prema tumačenju Snežane Milinković, Bokačo sagledava brak izvan okvira dvorsko-viteške i tradicionalno-hrišćanske etike, te uspostavlja drugačiju etiku ljubavi i braka. U viteškom konceptu ljubavi, prava ljubav je bez interesa - može da postoji samo izvan bračne zajednice, budući da brak predstavlja ekonomsko-interesnu zajednicu, dok tradicionalno hrišćansko shvatanje braka odbacuje mogućnost vanbračne ljubavi. Nova Bokačova etika sastoji se u tome da žena, ukoliko u braku ne nalazi ljubav i poštovanje, ima puno pravo da ih potraži na nekom drugom mestu. Da bi istakao svoju novinu, Bokačo je sve prevarene muževe pretvorio u „figure čija je osnovna odlika glupost" (Milinković 2011: 141). Pazolinijev muž koji se smeje kao magarac zaista vizuelno-auditivno otelotvoruje glupaka; iako smeha nema u tekstu, njegovim unošenjem Pazolini je, zapravo, ostao veran Bokaču, te se ova nova novela može smatrati primerom Endruovog ukrštanja. Pošto i ostale novele, izuzev priče o „Đotu“, u manjoj ili većoj meri spadaju u ukrštanje, postavlja se pitanje da li bi se film kao celina sačinjena od epizoda-ukrštanja mogao smatrati transformacijom?

Osim iz ugla tipologija adaptacije, koje više prave problema nego što ih rešavaju, Pazolinijevom Dekameronu kao adaptaciji može se pristupiti i na osnovu postavki Linde Hačn. Kanadska teoretičarka adaptaciju shvata u postmodernističkom ključu kao vrstu palimpsesta, kao ponavljanje s razlikom (,repetition with variation“), a što, prema autorkinom shvatanju, predstavlja glavni razlog zadovoljstva (jouissance) u adaptaciji (Hutcheon 2006: 4, 33-34). Naravno da bi bila anahrona greška posmatrati Pazolinijev (bilo koji) film kao postmodernistički. ${ }^{27}$ Budući da autorka svoje teze ilustruje primerima i iz prepostmodernističkih dela, njena zapažanja mogu se iskoristiti za rasvetljavanje smisla Pazolinijevih izmena. Studija Linde Hačn koncipirana je tako da se o fenomenu adaptacije raspravlja putem takozvanih novinarskih pitanja: „šta“ je adaptacija, „ko“ adaptira i „zašto“, „kako“ se adaptira, „kada“ i „gde“ se adaptira. Budući da je o pitanju „kako“ (publika) već bilo reči, a da se ispod pitanja „ko“ i „Zašto“ krije

27 Iako je Pazolini za sebe rekao da je pastišer, upotreba pastiša, jednog od ključnih postupaka postmodernizma, ne može biti dovoljan razlog da se neko svrsta u postmodernizam. 
intencija autora ${ }^{28}$, za analizu Dekamerona od najveće koristi cee biti odgovori na pitanja „šta“, „kada“ i „gde“.

Posmatrajući adaptaciju i kao proces, i kao završeno delo, Linda Hačn je određuje kao kreativnu i interpretativnu transpoziciju jednog ili više poznatih umetničkih dela, i to najčešcee, ali ne i nužno - u drugi medij. Kao primer transmedijalne transformacije može se navesti „prevođenje“ romana u operu: Dame s kamelijama Aleksandra Dime Sina u Travijatu Đuzepea Verdija; drame u film: tragedije Vilijama Šekspira (William Shakespeare) u film Baza Lurmana (Mark Anthony „Baz“ Luhrman) Romeo+Julija; romana u strip: Tarzana Edgara Rajsa Barouza (Edgar Rice Burroughs) kao strip prvi je ilustrovao Hal Foster (Hal Foster). Primeri su, neko bi rekao - bezbrojni. Kao primer adaptacije bez transformacije medija može se navesti roman Sati koji je Majkl Kaningam (Michael Cunningham) napisao na osnovu romana Virždinije Vulf (Virginia Woolf) Gospođa Dalovej, i komad Hamlet mašina Hajnera Milera (Heiner Müller) zasnovan na Šekspirovom Hamletu. Pazolinijev Dekameron, zbog „prevođenja“ novela na filmsko platno, iz pripovednog medija u predstavljački, kao adaptacija spada u transmedijalnu transformaciju.

Hačn ističe da promena medija uglavnom otvara raspravu o odnosu medija i njihovih razlika. Na primer, koji medij „bolje radi šta“ od drugog medija? Kao odgovor obično se navodi da romanu više „leži“ predstavljanje toka svesti nego filmu, a što je već pokazano na primeru Smrti u Veneciji. Genijalan Vendersov (Wim Wanders) film Nebo nad Berlinom u kome publika posmatra anđele dok slušaju misli ljudi, predstavlja redak primer (vrlo uspešnog) filmskog toka svesti, te kao i svaki izuzetak - samo potvrđuje pravilo. Podsetiću da se sa tim problemom suočio i sam Pazolini i koji je prelaskom s literature na film shvatio da nije u pitanju samo promena tehnike, već da svaki medij ima sopstveni jezik. Prema Lindi Hačn, postoje tri osnovna načina na

28 Što se pitanja ko adaptira tiče, Hačn je ukazala samo na to da kod dela u čijem stvaranju učestvuju dva ili više različitih umetnika - ostaje otvoreno pitanje ko adaptira. Ako je jasno da je Aleksandar Dima Sin (Alexandre Dumas, fils) adaptirao svoj roman Dama s kamelijama u pozorišni komad, pri transformaciji istog romana u operu Travijata, nije jasno ko je adaptirao tekst: kompozitor Đuzepe Verdi (Giuseppe Verdi), pisac libreta Frančesko Marija Pjave (Francesco Maria Piave) ili oba umetnika? Film koji nastaje saradnjom različitih umetnika: kostimografa, scenografa, kompozitora, glumica i glumaca, montažera, prema Hačn - predstavlja najsloženiji problem, iako se obično reditelj smatra „dežurnim krivcem“. Kao što je rečeno, Hačn je samo ukazala na postojanje problema, ali nije ponudila rešenje za njega. Na pitanje zašto se neko upušta u mučan proces adaptacije, teoretičarka kao potencijalne razloge navodi: 1) ekonomske uzroke (mogućnost ogromne zarade); 2) probleme sa autorskim pravima; 3) kulturni kapital: onaj koji adaptira klasike, čuva kanon i tradiciju i/ili nastoji da postigne ugled u okviru sopstvene profesije; 4) lične i političke motive (Hutcheon 2006: 86-95). 
koji se publika „uključuje“ u priče: pripovedanje (“telling”), predstavljanje ("showing") i participacija ("interacting")29, a kroz odnose ova tri načina autorka ispituje probleme transmedijalne adaptacije. Prva mogućnost jeste prebacivanje iz pripovedanja ("telling") u predstavljanje ("showing") i vice versa. Primeri bi bili filmska verzija Smrti $u$ Veneciji ili Andersonov (Kevin Anderson) roman nastao na osnovu istoimenog filma Liga izuzetnih džentlmena (2003). Druga mogućnost jeste prebacivanje iz predstavljanja ("showing") u predstavljanje ("showing”), iz jednog ,izvođačkog“ (,performativnog") medija u drugi, a za primer se može uzeti Britnova (Benjamin Britten) opera San letnje noći (1960) nastala na osnovu istoimene Šekspirove komedije. Oslanjajući se na shvatanje digitalnih medija Rajanove (Marie-Laure Ryan), Hačn piše i o prebacivanju iz pripovednih/predstavljačkih medija ("telling"/"showing") u participativne ("interacting") i vice ver$s a$ - primer su kompjuterske igre nastale na osnovu filmskih franšiza kao što su Ratovi zvezda Džorda Lukasa (George Lukas) ili Matriks Vačkovskijevih (The Wachowskis) (Hutcheon 2006: 15).30

Hačn je posebnu pažnju posvetila problemu transponovanja pripovednog teksta u predstavljački medij, primetivši da adaptiranjem romana u film ili predstavu iskrsavaju problemi koji se tiču igre glumaca kao što su gestovi, mimika ili boja glasa. O ovom problemu već je bilo reči pri analizi ekranizacije novele o Peroneli i objašnjavanju da Pazolinijeva intervencija (ekranizovanje smeha muža koji ne postoji eksplicitno u tekstu) aktivira značenje same novele. Kao drugi primer može se uzeti Mazetov „blesavi osmeh“ na koji je profesor Ilić skrenuo pažnju pri tumačenju Bokačove upotrebe detalja. Pazolini se njim obilato služi tokom čitave epizode kako bi, slobodno se može reći, slavio život i vođenje ljubavi. Kao treći primer može se navesti opet smeh.

29 „Three major ways we engage with stories (telling, showing, and interacting with them" (Hutcheon 2006: xiv) [kurzivom istakao P. M.].

30 Lindi Hačn se, međutim, mogu uputiti dve zamerke. Prva se tiče tipologije tri načina na koji je publika „uključena“ u priču. Autorka je aktivnost autora (pripovedanje i predstavljanje) i aktivnost publike (participacija), kreaciju i recepciju, dve različite oblasti, svela na istu ravan. Ako se poslužim analogijom, to bi značilo da su komponovanje klavirske kompozicije, izvođenje iste i njeno slušanje načini „bavljenja“ notama. Ako se tako pristupa problemu, onda bi se i štampanje i lepljenje nota, kao i brisanje prašine sa klavira moglo shvatiti kao „uključivanje“ u muziku i „bavljenje“ notama. Druga zamerka je ta što Hačn nije razmotrila sve moguće kombinacije između tri načina. Kao primer prebacivanja iz pripovedanja („telling“) u pripovedanje („telling“) može se uzeti već pomenuti roman Sati. Kada je o odnosu dva participativna medija („interacting“ - „interacting“) reč, kao ne baš najsrećniji primer, može se navesti Boalovo (Augusto Boal) legislativno pozorište. U ovom teatru, publika participira tako što tokom predstave ili na njenom kraju predlaže zakone ili njihovu izmenu u vezi sa problemom predočenim $u$ predstavi. Po završenom procesu, izvođači sakupljene predloge i rešenja predaju zakonodavnim vlastima, i na taj način učestvuju u participativnoj demokratiji. 
Pri ekranizaciji novele o Čapeletu, Pazolini je iskoristio zanimljiv detalj prisutan u samom tekstu. Prilikom junakove ispovesti fratru, zbog koje će on na kraju postati svetac, dvojica braće kod kojih je odseo i koji slušaju njegove laži - „prsnu u smeh“. Pazolini je „i sam istakao važnost ovog segmenta teksta“ jer se u sceni ispovesti „smenjuju kadrovi u kojima se čas vide Čapeleto i fratar, čas dvojica braće koji, skriveni iza dovratka, ne mogu da suzdrže smeh" (Milinković 2011: 107). U tekstu, a to je predstavljeno i na filmu, scena je postavljena kao dramska situacija, komad u komadu, braća su publika koja posmatra Čapeletovu predstavu. Preciznije rečeno, Čapeletov „pozorišni performance" uvodi dva tipa publike, braću koja znaju i koja se smeju, i fratra koji ne zna i ne shvata Čapeletovu literarnu obradu hagiografije (isto: 106). Čapeletova adaptacija žanra ispovesti bi, prema kriterijumima Linde Hačn, bila prava i uspešna, jer su obe publike, i upućena, i neupućena - zadovoljne, a to što je zbog neupućenosti fratra najgori čovek na svetu postao svetac, otvara pitanje za drugačiju vrste rasprave.

Kada je reč o pitanjima „kada“ i „gde“ , Linda Hačn (Hutcheon 2006: 141-167) shvata ih kao pitanja konteksta. Kao primer pomeranja $\mathrm{u}$ vremenu, ona navodi filmsku adaptaciju Tasovog (Torquato Tasso) Oslobođenog Jerusalima iz 1918. godine i primećuje da su u filmu, s jedne strane, predstavljene imperijalne težnje Italije iz perioda rata $\mathrm{u}$ Libiji (1911-1912), a sa druge, anticipirane buduće filmske adaptacije epova u periodu fašizma. ${ }^{31}$ Promenu prostora (pitanje „gde“) autorka naziva transkulturalnom adaptacijom, a kao primer navodi Krvavi presto (1957), Kurosavinu (黒澤明) adaptaciju Šekspirovog Magbeta u kome je radnja iz srednjovekovne Škotske prebačena u srednjovekovni Japan. Očigledno je da Linda Hačn u vezi sa vremenskim i prostornim pomeranjima raspravlja o dve vrste problema. Hipotetički govoreći, prebacivanje radnje Bokačovog Dekamerona u Japan dvadeset i prvog veka (promena hronotopa teksta) nije i ne može biti isto što i snimanje filma Dekameron u Japanu u dvadeset i prvom veku.

\section{„Đoto“/Pazolini}

Dekameron spada u transkulturalnu adaptaciju, budući da Pazolini veći zahvat ne pravi na temporalnom planu, već na nivou topografije. Film je sastavljen od devet epizoda i podeljen na dve celine: prvi deo filma (Andreučo, Mazeto, Peronela) uokviruje priča o Čapeletu, a drugi deo (slavujev poj, Lizabetin bosiljak, začarana kobila, dvojica

31 Prema Hačn, to je bio i jedan od razloga zašto adaptacija nije bila popularna $u$ antifašističkom neorealističkom filmu posle Drugog svetskog rata. 
Siježana) - priča o slikaru koji putuje u Napulj kako bi naslikao fresku Strašni sud u crkvi Santa Kjara (Repetto 1998: 116). Umesto Bokačove noseće priče u kojoj družina od sedam devojaka i tri mladića „odlučuje da ode izvan grada“ Firence, u kome vlada kuga, „na imanja, gde, $\mathrm{u}$ vrtu, tokom deset dana pripoveda sto novela, da bi se nakon dve nedelje“ izolovanog života „vratila tamo odakle je i krenula“ (Milinković 2011: 54), Pazolini postavlja dva okvira: Čapaleta i najboljeg učenika Đota.

Bokačova noseća priča dešava se 1348 . godine u vreme epidemije kuge, a Pazolinijeva okvirna priča o učeniku Đota na jugu Italije, kao i ostale novele u filmu - otprilike u to isto doba. ${ }^{32}$ Sto se mesta radnje tiče, Pazolini je značajno izmenio originalnu topografiju. Antonino Repeto (Repetto 1998: 118) piše da su sve epizode, izuzev priče o Čapeletu, smeštene na jug Italije, u Napulj i okolnu prirodu čime je Bokačov gradski i firentinski kontekst redukovan na narodski, na lumpen-proleterijat južne Italije. Ovom promenom, Pazolini postavlja čulnu prirodu ljubavi izvan građanskog kruga u „prirodno“, „ruralno“ okruženje, i time ostaje veran, kao što je već rečeno, Bokačovom shvatanju erosa kao prirodnog i u skladu sa prirodom.

Repeto je izneo još jedno zanimljivo zapažanje. Za razliku od Đotovog učenika koji se spušta na jug, Čapeleto zbog „posla“ putuje na sever, čime su dva Pazolinijeva okvira stavljena u jasan kontrapunkt. Opoziciju jug-sever dodatno naglašava sledeći likovni citat: pre poslednje ispovesti, publika posmatra Čapeleta koji posmatra „epidemiju kuge“, a ova je predstavljena na osnovu slika Borba Karnevala i Posta (1559) i Trijumf smrti (1562) Brojgela Starijeg (Pieter Brueghel), slikara sa severa. Sa prve slike, na primer, Pazolini preuzima „personifikaciju“ posta, „usukanu i neuglednu“ dok se suočava sa neprijateljem "naoružana' lopatom sa dve bedne haringe“ (Ruso 2012: 42). U filmu ova figura na lopati umesto ribica nosi lobanju. Sa druge slike, na kojoj je Brojgel ,utkao jednu od omiljenih tema srednjovekovne ikonografije: dolazak smrti zlokobnom zapregom“ (isto: 54) - Pazolini je preuzeo kolica puna lobanja. Umesto dva kostura koja kod Brojgela voze ova kolica, na filmu to čine dva muškarca obučena u crno. U poslednjem krupnom kadru Čapeleto vidi lobanju koju drži Post, i koja ga, kao i publiku, podseća da „smrt niko usitinu ne može izbeći: žene i muškarci, odrasli i deca, bogati i moćni, siromašni i nesrećni, vladari i crkveni poglavari“" (isto: 54 ).

Kontrast između dva Pazolinijeva okvira dodatno pojačava i razlika u vokaciji njihovih nosilaca. Za razliku od Čapeleta, ubice, lopova i

32 Đoto je zaista boravio u Napulju između 1328. i 1333. godine kada je radio na freskama u crkvi Santa Kjara i u zamku Kastel Nuovo (Mander 2012: 154). 
uterivača dugova, Đotov učenik je slikar, umetnik i sanjar. Opozicija između Čapaleta i Đotovog učenika, ubice i umetnika, smrti i stvaralačkog života, potencirana je i montažom: posle kadra u kome se vidi Čapeletovo beživotno telo koje postaje svetac, sledi kadar u kome Đotov učenik trči sklanjajući se od kiše. Opozicijom ruralni jug - gradski sever, životom i „profesijom“ ubice i umetnika, te načinom montaže, Pazolini je vizuelno otelotvorio opoziciju smrt - život, glavnu okosnicu u Bokačovoj nosećoj priči o deset mladih ljudi.

Prema tumačenju profesora Aleksandra Ilića, funkcija Bokačove noseće priče sastoji se u povezivanju priča različite tematike i sadržine 33 u jedinstvenu celinu, poput priče o Šeherezadi iz Hiljadu $i$ jedne noći. Šeherezadu je profesor tumačio kao metaforu za književnost putem koje se čovek suprotstavlja smrti i prolaznosti. Poznato je da je Bokačo noseću priču zasnovao na istorijskim činjenicama i stvarnoj epidemiji kuge koja je izbila u Firenci 1348. godine. Prikazivanje kuge kao „biča Božijeg“, bolesti kao kazne - skretao nam je profesor pažnju - predstavlja ostatke srednjovekovne kulture u Dekameronu, kao i susret sedam devojaka i tri mladića u Crkvi Santa Marija Novela (u srednjem veku svi važni događaji odvijaju se u crkvi). Opis bolesti protiv koje nije bilo leka, Bokačo daje detaljno i precizno, „naturalistički“, prema profesorovim rečima - kao iz nekog medicinskog leksikona:

I nije kao na Istoku, gdje je krvarenje iz nosa bilo očit znak neumitne smrti; već se odmah na početku, muškima kao i ženskima, pojavljivahu na preponama i pod pazusima neke otekline, koje bi narasle kao jabuka ili jaje [..., ] potom su se znaci bolesti izmijenili tako da bi se ruke i bedra osuli modrim ili crnim pjegama (Boccaccio 1991: 22). 34

Profesor Ilić je isticao da užasan strah od smrti dovodi do krize tokom koje sva moralna pravila pucaju. Suočeni sa katastrofom, ljudi različito reaguju, bežeći u ekstreme kao što su isposništvo ili hedonizam. Međutim, u svemu tome nestaje ljudska solidarnost, a kao vrhunac ljudske slabosti navodio je primere roditelja koji su ostavljali svoju decu: „očevi i majke izbjegavahu svoju djecu pohađati i njegovati kao da i nisu njihova" (Boccaccio 1991: 24). Budući da je strah od smrti

33 U srednjem veku uobičajeni nazivi za različite forme narratio brevis su favola, parabola i istoria. Bokačo ističe da se njegove novele mogu doživeti kao: favole, formalno elaborirani tekstovi nastali kao proizvod književnog stvaranja (inventio) i ponovnog ispisivanja manje ili više tradicionalnih tekstova; kao istorie, priče o stvarnim događajima, kao odlomci iz „crne“ hronike; parabole, primeri o kojima valja razmišljati da bi se izgradili određeni modeli ponašanja (Milinković 2011: 48).

34 Bokačov „naturalistički“ opis kuge predstavlja „savršeno književno-retorički ustrojeni tekst“ koji se poziva „na već poznate opise kuge“, poput onog Petra Đakona iz Historia Longobardorum (Milinković 2011: 56). 
jači od svega, prema Ilićevom tumačenju, Bokačo je o svemu tome pisao bez ijedne reči kritike, bez osude 35 , kao pravi humanista kome je u centru pažnje čovek kao slabo, krhko, grešno biće, koje beži od svog deteta, ali i kao čovek koji je sposoban za najviše, plemenite podvige poput Gizmonde iz novele o knezu Tankrediju. Profesor nam je skretao pažnju da se Bokačov humanizam koji konstatuje ljudske slabosti bez osude - može smestiti u široki kontekst opšte književnosti: „Ništa što je ljudsko nije mi strano“ (Terencije/Menandar) i „Sve razumeti, znači sve oprostiti“ (Dostojevski).

Spram priče o kugi, tanatosu, Bokačo kao kontrapunkt uvodi eros koji simboliše život i ljude, „veselu družinu“ koja je spremna da se odupre i bori protiv smrti koliko god je to mogucee. ${ }^{36}$ Bokačova odabrana družina odlazi na bajkovito i idilično mesto izvan grada zahvaćenog kugom, koje stoji u snažnom kontrastu spram smrću razorene Firence, na mesto gde će pripovedati prvenstveno o ljubavi i erosu kao životnom elanu. Iako je smrt najmoćnija i sve pobeđuje, profesor je isticao da Bokačo nije svoje delo počeo srećno, a završio nesrećno - već upravo obrnuto. 37 Iako idilično mesto na kome boravi družina možda nije moguće u stvarnosti, to ne znači da čovek ne treba da se suprotstavi svojoj nesreći, a u čemu mu pripovedanje (književnost, umetnost) može pomoći pružanjem utehe. ${ }^{38}$ Pazolini, kao da je slušao predavanja profesora Ilića, kada je pobedu života, erosa i umetnosti nad smrću, vizuelno ostvario putem suprotstavljanja okvira o Đotovom učeniku epizodi sa Čapaletom.

Najveća promena u odnosu na original svakako je priča o najboljem učeniku slikara Đota, koju Pazolini unosi kako bi ostao veran

35 Uporediti sa: „Bokačov opis kuge postaje obestrašćena i racionalna analiza društva koje se u trenutku krize raspada i urušava“, a „završna slika masovnih grobnica“ „bez ikakvog imena ili znaka“ „predstavlja kulminaciju totalnog uništenja“(Milinković 2011: 58).

36 Bokačova lieta brigata pokušava da sagradi društvo na novim osnovama, praveći neku vrstu izborne monarhije ili oligarhijske republike, u kojoj će svakog dana druga osoba biti kralj; pošto su glavni zadaci vlasti očuvanje života i stvaranje prilika da se oni provedu u dobru i sreći, obnova društva započinje pripovedanjem, a ne društvenim igrama poput šaha, u kojima se, za razliku od pripovedanja (književnosti), dobro i sreća ostvaruju na račun drugog (Milinković 2011: 58-61).

37 Uporediti sa: „Njihovo spasonosno putovanje iz pakla na zemlji u vrt, locus amoenus - samo je jedna od mnogih parodičnih imitacija Danteove Komedije“ (Milinković 2011: 55-56).

38 Pripovedanje ne spasava samo od neposredne smrti kao u Hiljadu i jednoj noći već pomaže u „osmišljavanju ovozemaljske realnosti“, a putovanje deset mladih ljudi predstavlja moralnu obnovu u skladu sa racionalnim zakonima prirode, koji se vraćaju u Firencu „u konačnoj pobedi koju je Život odneo nad Smrću“ (Milinković 2011: 68, 66). 
suštinskoj Bokačovoj ideji - pobedi (stvaralačkog) života nad smrću. Smatra se da je Pazolini inspiraciju za epizodu o slikaru našao u Bokačovoj kratkoj noveli (VI, 5), u kojoj se Đoto i njegov saputnik rugaju jedan drugom zbog prljavštine odeće i ružnog izgleda. Ako se pogleda filmska verzija u kojoj slikar luta ulicama i trgovima Napulja u potrazi za likovima i situacijama koje ce preneti na freske, izgleda da reditelju inspiraciju nije pružila radnja novele već slavljenje Đota kao jednog od najvećih umetnika svih vremena. Bokačo (Boccaccio 1991: 349) ubraja Đota među „najsjajnije zvijezde firentinske slave“:

Bio je tako neobično darovit da nije bilo takve stvari u prirodi, majci svega stvorenog i pokretateljici nebesa i svjetova, što on ne bi perom ili pisaljkom narisao ili kistom naslikao, i to tako vješto te ne bijaše samo slično prirodi već priroda sama; i tako se puno puta dogodilo da se ljudsko oko prevarilo, misleći da je stvarnost ono što je naslikao.

Đotovo slikarstvo koje kao da stvara „priroda sama“ - stoji u jasnom dosluhu sa Pazolinijevim stavom o filmskom mediju: „ako želim da izrazim drvo, izraziću ga kroz njega samog“. U jednom trenutku, tokom lutanja, slikar sklapa šake u gest tipičan za filmske reditelje kada „kadriraju“ prizor. Budući da slikara igra sam Pazolini, prema Repetu, ovo značenje se prenosi na ostale scene iz filma: priča o Đotovom učeniku Pazoliniju postaje metafora za stvaranje samoga filma, a sam Dekameron - san o filmu koji vizuelno predočava san o izgubljenom svetu lumpen-proleterijata i radosti življenja i erosa koji više ne postoji u bajkovitim slikama ondašnjeg bioskopa (Repetto 1998: 121-122).

Već je rečeno da zbog smeštanja priče o Đotovom učeniku, ali i ostalih novela, na jug, film Dekameron predstavlja transkulturalno pomeranje. Ovo postaje još očiglednije kada se filmska freska koju učenik pravi u crkvi Santa Kjara u Napulju, uporedi sa stvarnim Đotovim freskama iz Kapele Skrovenji u Padovi, nastalim između 1303. i 1305. godine. Na primer, i na stvarnim freskama, i na nedovršenoj filmskoj fresci - u gornjoj polovini slike dominira intenzivna plava boja neba. Freska koju filmski slikar stvara u crkvi Santa Kjara je triptih; na skici koju nosi sa sobom, Đotov učenik ima rešenje za levi i srednji deo triptiha, dok desni deo tek treba da osmisli. Deo koji nedostaje jeste i glavni razlog slikarevog lutanja po Napolju; on među narodom traži inspiraciju za završetak freske.

Osim za triptih, Đotove freske iz Kapele Skrovenji poslužile su kao inspiracija i za viziju u snu koju slikar doživljava pred sam kraj filma. U Kapeli Skrovenji naracija se „odvija u trideset osam prizora“, „pripovedanje teče linearno prema hronološkom sledu Hristovog života, od 
njegovih predaka do silaska Svetog duha posle njegovog vaskrsenja“ (Mander 2012: 74).39 „Krajnji cilj putanje“ u Kapeli Skrovenji jeste Strašni sud „kojim dominira figura Hrista“ i gde se vidi „jasna razlika između duševnog sklada blaženih i očaja prokletih“, koje plamena reka odvlači „u pakao“ (isto: 74). Vizuelno rešenje sna-vizije Pazolini je pronašao u Đotovom Strašnom sudu. Na primer, kadar u kome dečak na ramenu nosi maketu crkve odgovara delu sa stvarne freske na kome „Enriko Skrovenji“, „naručilac“ Đotovog dela, drži „malu maketu svoje kapele“ (isto: 108).

Pazolini je, međutim, napravio važnu izmenu u glavnoj figuri na fresci - unutar mandorle umesto Hrista, on smešta Devicu Mariju 40 koja drži Sina u naručju. Stefano Soči je ovu izmenu prokomentarisao sledećim rečima: „U stvarnosti na slici u Padovi Hrist je sudija“, dok je kod Pazolinija „Hrist zamenjen Bogorodicom, što govori o značaju lika majke u njegovom delu“ (Аранђеловић 2004: 77). Kada profesor Soči konstatuje da „Pazolini igra slikara Đota (ili Đota mučenika, to nije jasno definisano)“ (Аранђеловић 2004: 77), čini se da je to i zbog trake koju umetnik nosi oko glave. Traka nastala vizuelnim ugledanjem na Velaskezovog Vulkana, a čija je tema prevara i izdaja, u promenjenom kontekstu, može da asocira i na zavoj koji krije ili leči rane na glavi od venca od trnja, i time dodatno sugeriše predstavu o umetniku kao mučeniku.

I kao da zamršeni intertekstualni i intermedijalni odnosi u poslednjim scenama filma Pazoliniju nisu bili dovoljni. U poslednjem kadru, on je, kao Velaskezov kovač, okrenut gledaocima leđima. A publika, u svojevrsnom myse en abime, posmatra „Đota“ - Pazolinija koji posmatrajući nedovršeno delo, i nedostajući treći deo triptiha, izgovora čuvenu rečenicu: „Zašto ostvarati delo kada je tako lepo samo ga sanjati?" (Perché realizzare un' opera quand' è così bello sognarla soltanto). ${ }^{41}$

39 Analizu pojedinih prizora videti u: Mander 2012: 76-106.

40 Igra je Silvana Mangano (Silvana Mangano), glumica najpoznatija po svojoj ulozi u neorealističkom filmu Gorki pirinač (1949), sa kojim stiče međunarodni uspeh i slavu.

41 Eho kultne rečenice može se naći na kraju ispovedne proze Moj život bez mene, koju je Jasmina Tešanović (Tešanović 2013: 226) posvetila svom pokojnom ocu Gojku i svojoj pokojnoj domovini Jugoslaviji: „Zašto da pišemo remek dela, dovoljno je da ih zamišljamo? Zašto da ih zamišljamo, kad možemo da ih živimo? Ja tako živim“, kao i na kraju romana Nećemo o politici Branka Dimitrijevića (Dimitrijević 2011: 302), autora romana i scenarija za istoimeni film Oktoberfest: „Rekao je: 'Čemu ostvariti neko delo, kad je tako lepo samo sanjati ga?' [...] Molim vas da mi se svi pridružite u ovoj zdravici: Živeo Pazolini!“ 


\section{Literatura}

Abot, H. P. (2009). Uvod u teoriju proze. Beograd: Službeni glasnik.

Boccaccio, G. (1991). Dekameron. Sarajevo: Svijetlost.

Cook, D. A. (2016). A History of Narrative Film. New York: W.W. Norton \& Company.

Čale, F. / Zorić, M i dr. (1974). Povijest svjetske književnosti, knj. 4. Zagreb: Mladost.

Čerami, V. (2015). Predgovor. Pjer Paolo Pazolini, Iskusni momci. Beograd: Dereta. $5^{-11 .}$

Dimitrijević, B. (2011). Nećemo o politici (Živeo Pazolini!). Beograd: Čarobna knjiga.

Đorđi, R. (2012). Velaskez. Beograd: Knjiga komerc.

Feroni, Đ. 2005. Istorija italijanske književnosti, tom II. Podgorica: CID.

Gregor, U. / Patalas, E. (1998). Istorija filmske umetnosti. Beograd: Sfinga.

Guglielmino, S. / Grosser, H. (1988). Il Sistema letterario. Milano: Principato.

Hutcheon, L. (2006). A Theory of Adaptation. New York / London: Routledge.

Luzzi, J. (2014). Poesis in Pasolini. Luzzi, J., A Cinema of Poetry: Aesthetics of the Italian Art Film. Baltimore: Johns Hopkins University Press. $70-85$.

Mander, M. (2012). Đoto. Beograd: Knjiga komerc.

McFarlane, B. (2009). From Novel to Film: Backgrounds. Film Theory and Criticism. Braudy, L. / Cohen, M. (ed.). Oxford: Oxford University Press. 381-389.

Milinković, S. (2011). Dekameron: knjiga o ljubavi. Beograd: Arhipelag.

Mirčetić, P. (2017). Blue Blanche \& Jeanette Named Jasmine: Jasmine French - Pastiš Woodyja Allena. Zadar: [sic] - časopis za književnost, kulturu i književno prevođenje [On-line]. Dostupno preko: https://www. sic-journal.org/ArticleView.aspx?aid=472 [pristupljeno 7. maja 2020].

Pasolini, P. P. (2008). Il „cinema di poesia“. La sinelogia della vita. Pasolini, P. P., Saggi sulla letteratura e sull'arte I. Milano: Arnoldo Mondadori Editore. 1461-1488, 1680-1683.

Pazolini, P. P. (1984). Amado mio kome prethode Grešna dela. Beograd: Narodna knjiga.

Pazolini, P. P. (2015). Iskusni momci. Beograd: Dereta.

Pivac, A. (2012). Fragmenti o Pazoliniju. Pisanje smrti. Glišić, I., Moje druženje s Pazolinijem. Šabac: Kulturni centar Šabac. 60-77.

Repetto, A. (1998). Invito al cinema di Pier Paolo Pasolini. Milano: Mursia.

Ruso, V. d. (2012). Brojgel. Beograd: Knjiga komerc.

Sanders, J. (2006). Adaptation and Appropriation. New York / London: Routledge. 
Selenić, S. (2002). Dramski pravci XX veka. Beograd: Fakultet dramskih umetnosti.

Suhodolski, B. (1972). Moderna filozofija čoveka. Beograd: Nolit.

Tešanović, J. (2013). Moj život bez mene. Beograd: Rende.

Zigaina, G. (1991). Pasolini Between Enigma and Prophesy. Toronto: Exile Edition.

*

Аранђеловић, С. (2004). Пјер Паоло Пазолини: вечност визионара. Београд: Дом културе „Студентски град“.

\section{Predrag Mirčetić}

University of Belgrade, Faculty of Philology

\section{Giotto the dreamer in Pasolini’s the Decameron}

\section{- Summary -}

Pier Paolo Pasolini made the first part of his Trilogy of Life in 1971 based on The Decameron, a collection of short stories. In Pasolini's film, a student of the painter Giotto travels to Naples for artistic work, which forms a framework that connects the stories taken from Boccaccio's masterpiece. In this paper, I deal with the influence of Pasolini's literary and film poetics on the adaptation of The Decameron, his reinterpretation of Boccaccio's concept of love, and the transmedial role of Giotto and his art. The starting point for the interpretation of Pasolini's film The Decameron is the lectures of Professor Aleksandar Ilić on Boccaccio and the "four elements" of The Decameron: a new concept of love, criticism of the church, criticism of prejudice, and development of the modern novella.

Keywords: Pier Paolo Pasolini, The Decameron, Giovanni Boccaccio, Aleksandar Ilić. 